Journal of Educational Method and Technology Vol. 2 No. 3, Desember 2019

P-ISSN 2622-8459 E-ISSN 2622-8467

http://ejournal.unima.ac.id/index.php/jemtec

\title{
Students' Attitude Towards English Language Learning
}

\author{
S Herwiana ${ }^{1}$, E N Laili ${ }^{2}$ \\ 1,2Universitas Hasyim Asy'ari Tebuireng Jombang, Indonesia \\ corresponding author: ${ }^{1}$ herwianas@yahoo.com
}

\begin{abstract}
This study is try to find out the students' attitude towards English language learning in Jombang elementary schools. Attitude is one of the factors that influence the language acquisition. The study used qualitative research methodology. The data were gathered by using questionnaire. The findings showed that most of the students have positive attitude towards English. But, there is a finding that showed the students' competence in learning English is poor. Positive attitude did not influence their competence in acquiring English. Some suggestions for government to make a guide or curriculum of English teaching -learning in elementary school. So that the teachers know how to teach English for young learner appropriately.
\end{abstract}

\section{Introduction}

Foreign language teaching has been done at elementary school in Indonesia since curriculum 1994. As the effect of modern era, it is started from elementary school and time to time it is also taught in kindergarten. People believe that English is an important language that should be acquired. They also think that ability to speak English has very significant role to make a better life. It was the local government policy to teach English in elementary school. They thought that this subject was very important for students' future. Firstly, it was taught only at grade 4th, 5th and 6th. Then it was taught from grade 1st to 6 th. Now, since the government changed the curriculum to curriculum 2013 not all elementary schools have English. Because the government said that teaching English for children is not good for their language development. Moreover, Chodijah (2012) said that English in elementary school was developed as one of the local content subject in 1994 with the government rule to teach at grade 4th to 6th but it was ignored, they taught English started from grade 1st while in this stage the children still have to learn and speak Indonesian correctly. The children's cognitive ability does not ready to learn foreign language.

In curriculum 2013, the Minister of Education stated that English can be taught in elementary school but only as an extra-curricular. The government wants the children to learn Indonesian as their national language. Bahasa Indonesia is a compulsory subject and as their national identity. Based on the Minister statement above, some schools do not teach English. Additionally, the government do not prohibit the school to teach English. They still allow English to be taught in elementary school. It depends on the school policy whether they want to implement it or not. Then, it began with controversy among the school teachers and parents. 
They still want their children to learn English. Therefore, several schools in the city especially private schools still teach English as an extra-curricular but some schools under the rule of Ministry of Islamic Religion still teach English as a compulsory local content subject from grade 1st to 6th. While the public schools under the Ministry of Education and Culture who still teach English as an extra-curricular subject only teach grade 4 th to 6 th and some only for grade 6 th.

Even though the government said it was not good to teach English to the children, many schools still teach it. Whereas, there so many parents and students who complains about the teaching of English in elementary school. They said the lesson is difficult and not suitable for their children. Elementary English teacher teaches about grammar and translation which is not suitable for young learner. This condition make the students feel frustrated to learn English. Young learners' intellectual development still in concrete operational stages which means they are not able to learn abstract rules. In the process of teaching and learning there are also some points to be consider one of them is attitude. Teachers have to know their students' attitude due to the successful teaching and learning.

There are some factors that contributing the succeed in second language acquisition. Motivation, attitude, age, intelligence, aptitude, cognitive style and personality are the factors that affect in second language acquisition (Khasinah, 2014). Attitude is one of the important factors determining in the success of language learning. Attitude definition based on the oxford dictionary is the way that you behave toward someone or something that shows how you think and feel. Students' behave toward the language learning can give the impact of their language acquisition. As Lightbown \& Spada (2006, p.63) said that if the students have positive attitudes towards the speakers of the language, they will desire more contact with them. It means that the students will be more attracted to learn the language if they are interested with the target language. This positive attitude related to the target language will bring the motivation to the students to learn the target language enthusiastically.

According to Ellis (1985, p.292 cited in Khasinah, 2014) stated that attitude is sets of beliefs about factors as the language culture, their own culture, and classroom learning, teachers and learning task they have. The statement explains that the attitude is not only about the language culture but also about the classroom learning, the teachers who teach the language and kinds of the task of language learning that given to the students. The attitude in learning the language can be positive or negative. Positive language teaching- learning can give positive attitude to the students while negative classroom language learning can give negative effect. Therefore, the language teaching and learning should be positive because it can make positive atmosphere in the classroom, moreover it makes the students' attitude to learn language become positive. The more positive attitude students' have the more concerned they learn the language while the more negative attitude students' have the more apathetic they learn the language. (Gardner \& Lambert, 1972 cited in AlSobhi et al, 2018, p.1).

\section{Literature Review}

Many researchers had been studied attitude toward language learning. It is believed that attitude give influence to the impact of teaching and learning. In 
education field attitude plays a key role in admitting or refusing something (Primadi, p.2). There are some previous studies that concerned about attitude in language learning.

Al-Sobhi et al (2018) entitled "Arab ESL Secondary School Students' Attitude Toward English Spelling and Writing" said that learner's attitude is considered a key motivational component and an important nonlinguistic factor that influences second-language learning. His research findings indicated that the students' attitude toward the social use of English is the highest. There is a significant positive relationship between the students' attitude toward spelling and writing.

Noursi (2013) conducted research "Attitude Towards Learning English: The Case of the UAE Technological High School". His research was to identify applied technology high school students' attitudes towards learning English and to investigate whether the students' attitude is affected by the teacher's nativity. The findings showed that the vast majority of students had positive attitudes towards English learning and the teacher's nativity (native and non- native speaker of English) did not influence students' positive orientation toward English.

Kiziltan \& Atli (2013) conducted research entitled "Turkish Young Language Learners' Attitudes Towards English". The findings of the study have revealed that the pupils seem to have developed positive attitudes towards English language skills and sub skills, materials, the course book, and activities.

Alkaf (2013) his study "Students' Attitudes and Perceptions Towards Learning English". He wanted to find out the students' opinion of English language institute in King Abdulaziz University regarding the importance of English, whether they think it is difficult or not, and where the difficulty lies. The study showed that most students have a positive towards learning English and that they try to improve their English and to use the language even though there are a lot of demands on their time and few opportunities to practice their English.

Ahmed, S. (2015) studied "Attitudes Towards English Language Learning Among EFL Learners at UMSKAL". This study was to investigate the attitudes of the learners towards the use of English in different areas; the causes that may have influenced the effect of English learning for students and the perspectives of English learning among non-major English learners in Malaysia. Results of the qualitative analysis show that the attitude towards English language learning and using the language in various domains of usage is extremely positive. The data also revealed that most of the students had negative feelings or fear regarding classroom instructions in their learning experience. Students of different fields varied in attitudes towards English language learning in terms of domains of usage and focus of learning skills, which shows that a single curriculum or teaching methodology is not adequate.

Primadi et al (2014) entitled "Students' Attitude Toward English, Language Learning, and English Native Speaker". This study investigated students' attitude toward English, language learning, and English native speaker and factors affecting the attitudes. The findings showed that students' positive attitude may be caused by their motivation (instrumental and integrative).

The differences between the previous study and this study are the subjects are randomly selected from grade $4^{\text {th }}$ and grade 5 th from four public elementary schools 
where English as an extra-curricular, not as a compulsory subject and the teachers never have a workshop or training of English for young learner. Furthermore, there is no curriculum or guide of English language teaching in elementary school.

\section{The Significance of Learning Attitude}

Attitude has been known of one of the factors affecting language acquisition. Based on Noursi (2013, p.22) there are some importance of learning attitude;

1) An investigation into students' attitudes is an effective method by which language teachers, education planners, syllabus designers and researchers can obtain greater understanding into the language teaching and learning.

2) Students have different needs, preferences, beliefs, learning styles, and educational backgrounds, and imposition to change upon these factors can lead to negative reactions.

3) Students have views on the learning process and can articulate them.

Since English language teaching in elementary school has not had any curriculum design and has not been done correctly, it affects to the students' attitude and give negative behave of language teaching and learning. That's why this study focus on the students' attitude toward English regarding to improve the teaching method and also to develop the English curriculum in elementary school.

The students' attitude towards English is not only influenced by the students as an individual learner but also from the academic aspect for example the teacher, the facilities and etc. Therefore, the objective of this study is not only wants to investigate the attitude of the students at elementary school toward English but also including students' attitude from the teacher aspect, media, teaching method, material, media used in teaching and the competence.

\section{Methods}

This study was using descriptive qualitative research methodology. The instruments to take the data was observation and questionnaire sheet.

The sample was taken from four schools which are public schools under the management of Ministry of Education and Culture. They are SDN Jombang 2 and SDN Jombang 3 which are located in the city of Jombang, and SDN Kwaron 2 and SDN Cukir 1 which are located in the village. This schools were chosen as a representative of elementary schools in the city and village. In this school English is taught as an Extra-curricular. The respondents are 24 students from grade $4^{\text {th }}$ and $5^{\text {th }}$.

Technique of collecting data was taken by the questionnaire sheet which consist of 33 questions. The data were presented descriptively. Then it was described and concluded the results based on the sub-variable.

The data that gathered by questionnaire were analyzed quantitatively. Then, it was percentage by counting the frequency of appearance of "yes" and "no". After the computation, the results of each questionnaire in the form of the percentage are interpreted on the basis of the following criteria: 
Journal of Educational Method and Technology Vol. 2 No. 3, Desember 2019

P-ISSN 2622-8459 E-ISSN 2622-8467

http://ejournal.unima.ac.id/index.php/jemtec

\begin{tabular}{ll}
\hline Score (\%) & Criteria \\
\hline $86 \%-100 \%$ & Very good \\
$76 \%-85 \%$ & Good \\
$60 \%-75 \%$ & Fair \\
$55 \%-59 \%$ & Poor \\
$\leq 54 \%$ & Very poor \\
\hline
\end{tabular}

\section{Finding and Discussion}

Based on the questionnaire sheet, it was known whether the students give positive or negative response toward English and it can be seen how they response at the process of teaching and learning activity in the classroom.

\section{Students' Attitude Towards English}

The first variable is about students' attitude toward the subject, English. The question is about student's interest in English. Mostly students stated that they were interested in English. They were 22 students who answered "yes" and only 2 students answered "no". There were 91.6\% who interested in learning English. There were $83 \%$ students stated that they felt more active in questioning and answering when they were learning English. Although English is their foreign language but this subject did not make them difficult or shy in giving question and answer the lesson. Most of students were happy when learning English. From the data it can be concluded $87.5 \%$ students said happy, $8,3 \%$ students said they were not happy, and $4 \%$ students did not answer whether they were happy or not. Furthermore, $87.5 \%$ students felt that they had self confidence in learning English.

This variable consist of 4 sub-variables that indicate positive feeling about English as a subject. Most of the students had a great feeling about it. So it can be concluded that English is not uninteresting subject. English is not a deadly subject like Math. Elementary students like to learn English.

\section{Students Attitude Towards the Process of Teaching and Learning English Teacher performance}

The second variable is about the teacher performance in teaching English. The students said $62.5 \%$ the teachers' voice was not loud enough, while $33 \%$ students the voice was enough to hear when teaching English.

Next sub-variable is about teacher's competence in teaching English. All $100 \%$ students stated that their teacher was able and master to explain the lesson clearly when teaching English.

From the teachers' attitude in teaching English 67\% students said the teacher used humor or joke in teaching English while 33\% students said the teacher did not use joke. Furthermore, 95.8\% students said that their teacher were patient when teaching English. And the teacher also showed a good personality in the class, it could be seen that $91.6 \%$ students said "yes" and $8 \%$ students did not give answer.

From those three sub-variables, mostly students gave positive answer. It can be inferred that the teachers' performance when teaching English is quite good. 


\section{Teaching method}

The third variable is about the teaching method. This variable shows how the teacher teaches English in the class. The first sub-variable is about the teaching technique, $79 \%$ students said the teacher used good and creative technique in teaching English. While, 21\% students said their teacher did not use good technique. Additionally, 75\% students said the teacher used real life activity in giving example. The second sub-variable is whether the teacher used English. From the data 38\% students said the teacher used English when explaining the lesson, 58\% students said the teacher did not speak English, while 4\% students did not answer.

The third sub-variable whether the teacher used media in teaching English. There were $62.5 \%$ students said their teacher used media in teaching English. While, $41.6 \%$ students said their teacher did not use media in teaching English. In the variable of teachers' performance. They stated that $91.6 \%$ were satisfied when the teacher explained the lesson. And $95.8 \%$ students said the teacher explained the lesson clearly and exactly. When explaining vocabulary, 58\% students said the teacher translated the meaning of vocabulary and $71 \%$ students said that the teacher did not ask the students to find the difficult vocabulary by themselves. There were $87.5 \%$ students who liked the method used by the teacher, while $12.5 \%$ students did not like the teacher's method in teaching English. There were 70.8\% students said that the teacher used interesting media when teaching English.

\section{Classroom atmosphere}

Next variable is about the classroom atmosphere. There were $50 \%$ students said they liked whether they sit in a group or sit in the circle position. While the rest $50 \%$ students did not like to sit in the circle or they never sit in the group because their teacher never arranged the seat. The class did not have enough space to arrange the seat in the circle or other position so they were in the same position. The private elementary schools mostly never change the seat position because there are many students in a class. The number of the students' average 30-40, it makes the classroom very crowded with the desk and chair.

\section{Material}

Material that is used in teaching also correlate with successful teaching and learning. There were $62.5 \%$ students who said the teacher taught grammar and tenses, while 33\% said "no" and 4\% (1 students) did not answer "yes" or "no". There were $70.8 \%$ students said the teacher used clear and interesting picture. And $70.8 \%$ students said the teacher used the color in the picture was interesting. While in the reality based on the observation they used student's workbook (LKS) which is not colorful only black and white with small pictures. Furthermore, when the researcher observed in the class, the teacher did not use pictures as media or using LCD or other. They just wrote down everything in the whiteboard. So the students' answer about pictures and color seems vice versa with the reality.

\section{Media}

Media is also one of the important source in teaching. It can make the explanation more clearly and understandable. There were $67 \%$ students said the 
teacher used many kinds of media, they were pictures, songs, LCD etc. There were $88 \%$ students said the teacher was skillful in using the media. And $88 \%$ students said that the media used in the teaching and learning activity was suitable with the lesson. In fact, based on the observation and interview, the use of media is very rarely used in the class.

\section{Competence}

One significant factor that influence the student's achievement is competence. The individual differences can cause the succeed in learning. So every student has different competence in acquiring the language. There were $50 \%$ students said that they could understand structure and sentence in English while the rest 50\% students did not understand English sentences. In addition, there were $67 \%$ or 16 students felt difficult in learning English and only 29\% or 7 students said that they did not feel difficult in learning English. Furthermore, 50\% students said they were easily to understand English vocabulary and the rest 50\% they said that English vocabulary was not easy to understand. Unfortunately, $62.5 \%$ students said that the teacher never used games to improve the students' vocabulary. And there were $62.5 \%$ students said that they were difficult to remember vocabulary in English. Moreover, $71 \%$ students said that they could not concentrate for a long period when learning English.

Finding that the most of the students could not remember the vocabulary easily, it is not surprised because this result correlate with the theory that children have weak memory, the storage and recall of young learner is not complete yet (Paradowski, 2008).

Furthermore, the result also showed that most of the students could not concentrate for a long time. This is also in line with Paradowski (2008) statements' that children have a short attention and concentration span. They are not able to learn grammatical structures or complete sentences.

Based on the data that was taken from the questionnaire most of the students gave positive responses in teachers' performance, teaching method, classroom atmosphere, material, and media. Those variable mostly got good responses. Even though most of the variables above had good responses, one variable (competence) did not get good result. This variable got poor result. Most of students gave negative answer in competence.

\section{Conclusions}

From the findings it can be inferred that the students' attitude toward English in SDN Jombang 2, Jombang 3, SDN Kwaron 2, and SDN Cukir1 have positive attitude. They are relatively having good response to the English as a subject.

They said they are interested, happy, active and have self confidence in learning English.

The students' attitude at the process of teaching and learning English is mostly good. There are six variables including the teachers' performance, the teaching method, the classroom atmosphere, the material, media and students' competence. From the six variables, only one variable which showed poor response. Students' competence is disappointed. 
The last variable (competence) has four sub-variables, they are understanding the meaning, structure and sentences in English; difficulty; vocabulary; and concentration. These four sub-variables have negative response. Most of the students said that English is difficult. They do not understand the vocabulary and the structure. Additionally, they said they cannot concentrate for a long time period.

Even though, the elementary students are happy and interested in learning English but their competence is not ready or even mature to get the lesson. The teaching and learning activities should be effective if the students feel happy. Bringing joyful and happiness in the class can make activities in the class effective because it gives valuable information processing and long-term memory storage (Singh, 2014, p. 11-12).

In conclusion, the positive attitude that the students' have according to the findings above, does not influence their competence in acquiring the language. As mentioned before that if the students' have positive attitude in language learning the more they attracted in learning the target language. But this fact stated that positive attitude does not make the students easily to learn the language. The students like to learn English but they think English is difficult.

It can be interpreted that there is something wrong in conducting the teaching and learning English. May be, it is about the method used by the teacher or the lesson (material) is not suitable for the elementary students. Chodijah added (2012) that English in elementary school is simple, easy and fun, to grow the students' happiness and realize that there is a foreign language that can be used as an alternative of communication but the elementary English teacher uses book from the private publisher and the objective of learning English at elementary school is different from the goal so it makes the burden.

Therefore, the government should make a guide or curriculum of English language teaching in elementary school so that the teacher will not teach unrelated material which is not appropriate with elementary students' intellectual development. Furthermore, the teacher has to use interesting teaching method, media and book in teaching English.

\section{References}

Ahmed, S. 2015. Attitudes Towards English Language Learning Among EFL Learners at UMSKAL. Journal of Education and Practice, (online), 6(18), (https://files.eric.ed.gov/fulltext/EJ1079681.pdf), accessed on 9 February 2019.

Alkaf, A.A. 2013. Students' Attitudes and Perceptions Towards Learning English. Arab World English Journal, (online), 4(2),

(https://awej.org/images/AllIssues/Volume4/Volume4Number2June2 013/8.pdf), accessed on 1 January 2019.

Al-Sobhi, B. et al. 2018. Arab ESL Secondary School Students' Attitude Toward English Spelling and Writing. SAGE Journal, (online), 8(1), (https://journals.sagepub.com/doi/pdf/10.1177/2158244018763477), accessed on 7 April 2019. 
Journal of Educational Method and Technology Vol. 2 No. 3, Desember 2019

P-ISSN 2622-8459 E-ISSN 2622-8467

http://ejournal.unima.ac.id/index.php/jemtec

Chodijah, I. (2012, October 30). Pelajaran Bahasa Inggris di SD Perlu Perbaikan.

Kompas. Retrieved from

(https://sains.kompas.com/read/2012/10/30/09472194/pelajaran.bahasa.inggri

s.di.sd.perlu. perbaikan)

Khasinah, S. 2014. Factors Influencing Second Language Acquisition. Journal of

Language, Education and Humanities, (online), 1(2),

(https://www.jurnal.ar-raniry.ac.id/index.php/englisia/article/view/187), accessed on 7 May 2019.

Kiziltan, N., \& Atli, I. 2013. Turkish young language learners' attitudes towards English. Hacettepe University Journal of Education, (online), 28(2), (http://www.efdergi.hacettepe.edu.tr/yonetim/icerik/makaleler/181published.pdf), accessed on 5 May 2019.

Lightbown, P.M\& Spada, N. 2006. How Languages are Learned. Third Edition. Oxford: Oxford University Press.

Noursi.2013. Attitude Towards Learning English: The Case of the UAE Technological High School. Educational Research, (online), 4 (1), (https://www.researchgate.net/publication/312212920_Attitude_towards_Lea rning_Engli sh_The_case_of_the_UAE_Technological_High_School), accessed on 5 May 2019.

Oxford Dictionary,(online), (https://www.oxfordlearnersdictionaries.com/definition/american_english/atti tude)

Paradowski, M. B. (2008, November 15). Young Learner Characteristics. Retrieved from https://sciencebin.wordpress.com/article/young- learner-characteristics2qpvzotrrhys 1-26/.

Primadi, et.al.2014. Students' Attitude Toward English, Language Learning, and English Native Speaker. UNILA Jurnal of English Teaching, 3(8), (http://jurnal.fkip.unila.ac.id/index.php/123/article/view/6691/4123), accessed on 8 May 2019.

Singh, S. (2014). Creating a Joyful Learning Environment at Primary Level. Shaikshik Parisamvad an International Journal of Education, 4(1), 10-14, Retrieved from http://www.spijebhu.in/SPIJan14p10-14.pdf. 